\title{
ANALISIS STRATEGI PEMASARAN KAIN ENDEK BALI SEBAGAI INDUSTRI PARIWISATA KREATIF (STUDI KASUS DENPASAR)
}

\author{
Deannisa Hakika Putri \\ I Wayan Suardana \\ I GPB Sasrawan Mananda \\ Email : deannisa@gmail.com \\ PS. S1 Industri Perjalanan Wisata \\ Fakultas Pariwisata UNUD
}

\begin{abstract}
ABSTRAK
Sebagai daerah tujuan wisata dengan jumlah kunjungan wisatawan terbanyak nomor dua di Indonesia, Bali perlu menyediakan fasilitas pariwisata yang baik. Begitu juga dalam hal cinderamata. Cinderamata memiliki nilai emosi yang tinggi karena cinderamata dapat memberikan kenangan bagi wisatawan yang membuat wisatawan ingin mengunjungi kembali daerah tujuan wisata tersebut. Peraturan Menteri Pariwisata dan Ekonomi Kreatif menyatakan bahwa industri kreatif dapat berkontribusi untuk meningkatkan Produk Domestik Bruto (DBP) nasional yang diperoleh dari nilai tambah yang dihasilkan oleh 14 industri kreatif, salah satunya adalah industri kerajinan. Karena itulah perlu dilakukan penelitian tentang strategi pemasaran untuk industri kreatif Kain Endek Bali sebagai cinderamata khas Bali dengan fokus Kota Denpasar. Metode pengumpulan data yang digunakan adalah observasi, wawancara dan studi kepustakaan. Teknik analisis data yang digunakan adalah analisis deskriptif kualitatif yang dianalisis dengan bauran pemasaran meliputi produk, harga, promosi, dan distribusi. Kemudian dipadukan dengan Analisis SWOT. Hasil penelitian ini menunjukkan bahwa strategi yang dapat diterapkan adalah; SO mempertahankan kualitas produk dan aktif mengikuti pameran-pameran, ST meningkatkan mutu produk dan tetap menggunakan sistem distribusi langsung, WO memperbaiki ruang produksi dan WT membuka cabang di daerah lain. Saran yang dapat diberikan adalah bekerjasama dengan agen perjalanan, pemerintah agar konsisten dalam mendukung kelestarian Kain Endek Bali, mempertahankan kualitas produk, dan mengemas hasil produksi dengan lebih menarik.
\end{abstract}

Kata kunci: Pemasaran, Industri Pariwisata Kreatif, Kain Endek.

\section{PENDAHULUAN}

Menurut data statistik tahun 2014

dari Badan Pusat Statistik (BPS), Bali merupakan daerah yang paling banyak dikunjungi wisatawan nomor dua setelah Jakarta dengan total 24.420 wisatawan baik wisatawan domestik maupun mancanegara per hari, diikuti Jawa Barat dan Jawa Tengah. Sebagai salah satu daerah dengan kunjungan wisatawan terbanyak, tentunya Bali harus menyediakan objek-objek wisata yang menarik dan tidak membosankan. Begitu pun dalam hal cinderamata khas Bali, tentunya harus menarik, tidak membosankan dan berbeda dari daerah lain karena cinderamata merupakan kenang-kenangan yang nantinya akan membuat wisatawan ingat dengan kenangan perjalanan yang 
dilakukan di Bali dan membuat wisatawan ingin datang kembali ke Bali. Ada satu kerajinan khas Bali yang cenderung terlupakan untuk dijadikan cinderamata, yaitu Kain Endek Bali. Kain Endek Bali sangat cocok untuk dijadikan barang cinderamata dan industri pariwisata kreatif yang baru karena Kain Endek merupakan kain khas Bali dan berbeda dari kain tenun lainnya karena tidak memakai mesin. Selain itu, dengan dijadikannya Kain Endek Bali sebagai industri pariwisata kreatif, tentu dapat menjadi sumber pendapatan yang lebih bagi para perajin Kain Endek Bali. Berdasarkan latar belakang masalah di atas, maka akan dilakukan penelitian tentang analisis strategi pemasaran Kain Endek Bali sebagai industri pariwisata kreatif dengan studi kasus Denpasar dengan rumusan masalah "Bagaimana strategi pemasaran Kain Endek Bali Kota Denpasar sehingga bisa menjadi industri pariwisata kreatif di Denpasar?" dan tujuan "Untuk mencari strategi dalam memasarkan Kain Endek Bali Kota Denpasar sehingga dapat menjadi industri pariwisata kreatif di Denpasar".

Manfaat akademik yang diharapkan dari penelitian ini adalah untuk menambah wawasan tentang strategi pemasaran industri pariwisata kreatif dan mengaplikasikan pengetahuan tentang Industri Perjalanan Wisata yang sudah didapatkan di bangku kuliah. Selain itu, agar juga dapat memberikan ide baru di industri pariwisata kreatif. Sedangkan manfaat praktis yang diharapkan adalah sebagai bahan masukan untuk ide industri pariwisata kreatif sehingga diharapkan dapat menjadi bahan pertimbangan terhadap industri pariwisata kreatif di Bali khususnya Denpasar.

\section{METODE}

Penelitian ini dilakukan di pusat perajin Kain Endek Bali di Sekar Jepun karena Sekar Jepun tergabung dalam organisasi bagi para perajin Kain Endek Bali dan tenun ikat lainnya untuk Kota Denpasar yaitu Asosiasi Bordir, Endek dan Songket (ASBES). Untuk membatasi permasalahan dalam penelitian ini, adapun definisi dari "Analisis Strategi" adalah sebuah upaya dan proses untuk menjelaskan strategi yang mungkin dilakukan berdasarkan data yang terkumpul dan diolah dengan menggunakan matriks SWOT. Selanjutnya, pemasaran yang dimaksud di sini adalah bagaimana memasarkan Kain Endek Bali. Kain Endek Bali di sini dipusatkan pada Kain Endek Bali area Denpasar yang diproduksi oleh perajin Kain Endek Bali di Sekar Jepun, Denpasar dan Industri pariwisata kreatif yang dimaksud adalah ide segar untuk oleholeh atau cinderamata bagi para wisatawan dan menjadi tambahan penghasilan para perajin Kain Endek Bali khususnya untuk perajin di area Denpasar.

Adapun jenis data yang digunakan adalah data kualitatif dan data kuantitatif. Sedangkan sumber data yang digunakan adalah data primer dan data sekunder. Teknik pengumpulan data yang digunakan adalah observasi, wawancara, dan studi kepustakaan. Teknik analisis data yang digunakan adalah teknik analisis deskriptif kualitatif yang kemudian dipadukan dengan pendekatan analisis SWOT.

\section{PEMBAHASAN}

Hasil dari penelitian ini yang diperoleh melalui proses wawancara adalah mengenai sejarah berdirinya Sekar Jepun yang berawal dari ketertarikan Ibu Etmy selaku pendiri Sekar Jepun terhadap dunia fashion. Ketertarikannya tersebut membuat beliau belajar menjahit dan meneruskan hobi tersebut menjadi usaha tenun ikat Kain Endek Bali dan mendirikan Sekar Jepun. Bahan baku yang diperlukan untuk memproduksi Kain Endek Bali hanya benang katun, benang sutera dan cat. Semua bahan baku tersebut diperoleh dari India. Proses pembuatan Kain Endek Bali adalah 
persiapan lusi, persiapan pakan, penenunan, dan penyelesaian. Produk yang dihasilkan oleh Sekar Jepun adalah Kain Endek Bali yang kemudian dibagi menjadi tiga jenis yaitu Katun, Katun Sutera, dan Sutera. Pameran-pameran yang sudah dilakukan oleh Sekar Jepun mayoritas pameranpameran yang diselenggarakan oleh pemerintah seperti Pekan Kesenian Bali, Wastra, dan Jakarta Food and Fashion Festival di Jakarta. Sekar Jepun menggunakan distribusi langsung kepada konsumen, tidak melalui perantara apapun.

Kelebihan dari Endek Sekar Jepun adalah kualitasnya yang tidak pernah mengecewakan, jahitan yang rapi, warna dan motif Endek Sekar Jepun yang khas dan tidak ditemukan di perajin lainnya. Kekurangan dari Endek Sekar Jepun adalah tampilan toko yang kurang atraktif dan ruang produksi yang kurang nyaman. Peluang yang dimiliki oleh Sekar Jepun adalah dukungan dan bantuan yang datang dari pihak dinas dan pemerintah, gaya hidup saat ini yang kerap menggunakan sesuatu yang berbau tradisional sebagai tren saat ini, dan lokasi Sekar Jepun yang terletak di Denpasar. Kendala yang dihadapi Sekar Jepun adalah permintaan pasar yang tidak menentu, sulitnya merekrut perajin-perajin lainnya untuk memenuhi permintaan konsumen, konsumen yang berasal dari kalangan atas sehingga banyak permintaan konsumen yang macam-macam namun harus tetap dipenuhi.

Pembahasan penelitian ini akan dibahas dengan strategi bauran pemasaran, analisis SWOT dan strategi pemasaran. Empat poin bauran pemasaran untuk dibahas adalah produk, harga, distribusi, dan promosi. Dari sisi produk, Sekar Jepun hanya memproduksi kain dan tidak diolah menjadi pakaian, tas, atau aksesoris lainnya. Produk Sekar Jepun juga konsisten dengan ciri khasnya yaitu kualitas yang baik dan warna-warna kain yang tidak terlalu terang.
Produk-produk ini dikerjakan dan dihasilkan oleh para perajin Sekar Jepun yang berasal dari Bali dengan bahan-bahan terbaik dan bahan baku impor dari India. Produk-produk Sekar Jepun juga tidak pasaran karena Sekar Jepun membatasi kuantitas kain yang akan diproduksi untuk satu desain.

Dari sisi harga, penentuan harga oleh Sekar Jepun tergantung pada ukuran kain yang diproduksi serta warna dan motif yang dihasilkan. Apabila kain tersebut mempunyai banyak warna dengan motif yang rumit dan indah, tentu harganya akan lebih tinggi dibandingkan dengan kain yang tidak memiliki terlalu banyak paduan warna dan motif yang sederhana.

Dalam hal distribusi, Sekar Jepun memakai saluran distribusi langsung yang berarti tidak ada perantara antara Sekar Jepun dengan konsumen. Sedangkan untuk hal promosi, Sekar Jepun melaksanakan tiga kegiatan promosi yaitu advertensi seperti brosur, personal selling atau penjualan langsung di toko Sekar Jepun, dan sales promotion seperti pameran atau demonstrasi yang sering dilakukan oleh Sekar Jepun.

Melihat konsep bauran pemasaran di atas, maka selanjutnya dianalisis faktorfaktor SWOT Kain Endek Bali di Sekar Jepun. Adapun kekuatan Kain Endek Bali di Sekar Jepun secara produk adalah menawarkan kualitas yang tidak pernah mengecewakan, memiliki jahitan yang kuat dan rapi, dan memiliki warna dan motif yang khas dan tidak dapat ditemukan di perajin lain. Kekuatan dari sisi harga adalah Harga Endek Sekar Jepun berbeda-beda tergantung dengan warna dan motif sehingga konsumen dapat memilih warna dan motif yang sesuai dengan budget pembeli dan Harga Endek Sekar Jepun sangat sesuai untuk konsumen kalangan atas. Dari sisi distribusi, kekuatannya adalah menggunakan sistem distribusi langsung sehingga dapat dipastikan produk sampai di tangan konsumen dengan baik yang juga 
membuat Sekar Jepun dapat mengetahui keinginan, kebutuhan dan masukan dari konsumen. Sedangkan secara promosi, kekuatannya adalah aktif dalam mengikuti pameran-pameran, dan memiliki jaringan yang luas untuk kalangan atas.

Adapun kelemahan Kain Endek Bali di Sekar Jepun dari sisi produk adalah tampilan toko Sekar Jepun kurang menarik dan atraktif serta ruang produksi Sekar Jepun kurang nyaman. Kelemahan dari faktor harga adalah cenderung mahal sehingga hanya sesuai untuk kalangan atas dan kurang cocok untuk dibeli oleh masyarakat menengah ke bawah dan harga tidak tercantum dengan jelas di produk yang ditampilkan. Dari sisi distribusi, kelemahannya adalah menggunakan sistem distribusi langsung sehingga persebaran dan ruang lingkup pemasaran Endek Sekar Jepun cenderung lebih sempit dan tidak memiliki cabang, galeri atau showroom lainnya. Kelemahan dalam hal promosi adalah masih belum bekerjasama dengan agen perjalanan untuk memasukkan Sekar Jepun sebagai toko oleh-oleh untuk dikunjungi, promosi di internet tidak up to date dan brosur yang dibuat oleh Sekar Jepun kurang menarik.

Peluang yang dimiliki Kain Endek Bali di Sekar Jepun dari sisi produk adalah mendapat banyak bantuan dan dukungan dari pemerintah dan sudah dikenal oleh konsumen kalangan atas. Dari sisi harga, peluang yang dimiliki adalah harga yang tinggi membuat Sekar Jepun lebih mudah dalam meyakinkan konsumen dalam hal kualitas dan perajin lain menjual produknya dengan harga yang lebih murah sehingga membuat Endek Sekar Jepun mempunyai citra yang lebih baik. Dari sisi distribusi, peluangnya adalah berlokasi di Kota Denpasar sehingga memudahkan konsumen untuk mengunjungi dan Sekar Jepun dan banyaknya perusahaan kargo yang memudahkan Sekar Jepun untuk mendistribusikan produknya ke luar Bali. Peluang dari sisi promosi adalah gaya hidup saat ini kerap menggunakan sesuatu yang berbau tradisional sebagai tren saat ini dan banyaknya pameran-pameran yang diselenggarakan yang bisa diikuti oleh Sekar Jepun.

Lalu, ancaman yang dihadapi Kain Endek Bali di Sekar Jepun dari sisi produk adalah sulitnya merekrut perajin untuk memenuhi permintaan konsumen, munculnya perajin-perajin lain yang berdiri yang juga menjual Kain Endek Bali, dan permintaan konsumen yang tidak menentu. Dari sisi harga, ancamannya adalah cenderung di atas rata-rata sehingga dapat mengakibatkan konsumen lebih memilih untuk membeli Kain Endek Bali dari perajin lain dan konsumen yang sangat sensitif terhadap harga. Dalam hal distribusi, ancamannya adalah masih sedikit perusahaan atau pusat oleh-oleh yang bersedia menjadi perantara atau distributor dan masih belum melakukan pengiriman kain untuk konsumen luar Bali. Ancaman dari sisi promosi adalah konsumen lebih memilih produk yang ditawarkan melalui iklan atau internet dan dikemas secara menarik dan perajin yang lebih kecil yang melakukan promosi dengan liar dan tidak tertib.

Berdasarkan analisis SWOT di atas, maka strategi yang dapat dilaksanakan adalah Strategi SO yaitu mempertahankan kualitas produk yang tidak mengecewakan (S) agar semakin dikenal konsumen (O) dan aktif mengikuti pameran-pameran (S) agar lebih mudah dalam memperkenalkan produknya lebih jauh kepada konsumen (O) terutama konsumen kalangan atas. Strategi ST yang dapat dijalankan adalah meningkatkan mutu produk yang sudah berkualitas (S) untuk mengatasi persaingan dengan perajin lain (T) dan tetap menggunakan sistem distribusi langsung untuk meyakinkan bahwa produk sampai di 
tangan konsumen dengan baik dan untuk mengetahui kebutuhan konsumen (S) untuk menghindari adanya citra buruk akibat dari tidak tertibnya perajin-perajin kecil dalam memasarkan produknya (T). Strategi WO yang dapat dijalankan adalah memperbaiki atau merenovasi ruang produksi yang kurang nyaman (W) menggunakan bantuan dari pemerintah (O) dan mencantumkan harga dengan jelas di setiap produk yang dijual (W) untuk meyakinkan konsumen mengenai kualitas produk (O) sehingga transaksi dapat dilakukan. Kemudian, strategi WT yang dapat dilakukan adalah $\mathrm{m}$ embuka cabang, galeri atau showroom di lokasi lain (W) untuk memenuhi permintaan konsumen di luar (T), memperbaiki bentuk promosi dari internet dan membuatnya lebih atraktif dan menarik (W) untuk memenuhi keinginan konsumen yang lebih produk yang dipasarkan melalui internet dan dikemas secara menarik (T), dan mencantumkan harga dengan jelas di setiap jenis produk yang dijual (W) untuk mengurangi sensitifitas konsumen terhadap harga produk $(\mathrm{T})$.

\section{SIMPULAN DAN SARAN}

Sebagai simpulan, ada beberapa alternatif strategi yang dapat diterapkan dalam pemasaran Kain Endek Bali, antara lain mempertahankan kualitas produk yang tidak mengecewakan, aktif mengikuti pameran-pameran, tetap menggunakan sistem distribusi langsung, memperbaiki atau merenovasi ruang produksi yang kurang nyaman menggunakan bantuan dari pemerintah, mencantumkan harga dengan jelas di setiap produk yang dijual, membuka cabang, galeri atau showroom di lokasi lain, serta membuat brosur dan promosi internet lebih atraktif dan menarik.

Saran yang dapat diberikan adalah membuka cabang, galeri atau showroom di daerah lain, lebih memanfaatkan fasilitas dan dukungan yang diberikan oleh pemerintah, memperbaiki situs internet Endek Sekar Jepun yang sudah ada, mengemas hasil produksi dengan lebih menarik, bekerjasama dengan agen perjalanan agar mengunjungi Sekar Jepun, menjaga kelestarian Kain Endek Bali dan mewariskan kepada anak cucu agar tidak musnah oleh perkembangan zaman, pemerintah supaya tetap konsisten dalam membimbing Sekar Jepun dan tetap memberikan dukungan dalam melestarikan Kain Endek Bali, harga produk Endek Sekar Jepun harus jelas dan konsisten, mempertahankan kualitas produk dan tetap menggunakan bahan baku serta alat yang baik dan memadai, dan tetap berpegang pada standar kualitas Endek Sekar Jepun untuk menjaga loyalitas konsumen.

\section{DAFTAR PUSTAKA}

Assauri, Sofjan. 1987. Manajemen Pemasaran: Dasar, Konsep dan Strategi. Jakarta: Rajawali

Damardjati, R.S. 1995. Istilah-istilah Dunia Pariwisata. Jakarta: Pradnyana Paramitha

Ermayanti. 2000. Kain Songket Palembang sebagai Daya Tarik Wisatawan di Provinsi Sumatera Selatan. (Sebuah Laporan Akhir)

Rangkuti, Freddy. 2002. Analisis SWOT Teknik Membedah Kasus Bisnis. Jakarta: PT Gramedia

S.B, Merylia E Imel. 2005. Strategi Pemasaran Tenun Ikat di Kabupaten Sikka Provinsi Nusa Tenggara Timur. (Sebuah Laporan Akhir)

Sandjaja, B dan Heriyanto, Albertus. 2006. Panduan Penelitian. Jakarta: Prestasi Pustaka Publisher

Sugiono.2010. Metode Penelitian Kuantitatif Kualitatif. Bandung: Alfabeta 
Swastha, Basu DH dan Drs MBA. 1996. Azas-azas Marketing. Yogyakarta: Liberty

dan Irawan. 1997. Manajemen Pemasaran Pariwisata Modern, Edisi Kelima. Yogyakarta: Liberty

Tjiptono, Fandy. 2001. Strategi Pemasaran, Edisi Kedua. Yogyakarta: Andi Yogyakarta

Yoeti, Drs. H. Oka A. 1996. Anatomi Pariwisata. Bandung: Angkasa 